criticism of it in the interests of justice and of sound morality. on the only possible basis, a single standard for both sexes. Very truly yours,

Howard A. Kelly.

"Unchastity and CRedibility. - 'For a considerable time,' says the Journal of the American Medical Association, 'the rule permitting a witness to be impeached by proof of general reputation for unchastity was confined, in Missouri, to females. Then the supreme court of the State held, in two cases, that the rule applied alike to both sexes, and that such reputation might be shown to discredit a male as well as a female witness. Now, in the case of State v. Sibley, the court, with three justices dissenting, overrules those two cases and reverts to its original position. Especially in a case where the defendant's character for chastity is directly involved, does the court think that such evidence is inadmissible for the purpose of impeaching his character as a witness. It is a matter of common knowledge, the court goes on to say, that the bad character of a man for chastity does not even in the remotest degree affect his character for truth, when based on that alone while it does that of a woman. It is no compliment to a woman to measure her character for truth by the same standard that you do that of man's, predicated upon character for chastity. What destroys the standing of the one, in all walks of life, has no effect on the standing for truth of the other.'

"This decision appears to us an abominably bad one. Either the court should decline to entertain the question of chastity in man or woman - and this would be by far the most equitable solution - or it should entertain it in both. To base upon the fact that woman's conduct is gauged by one moral standard and man's by another, a still further injustice, by which a woman who does that which is disregarded when done by a man is made a semi-outlaw, appears to us monstrous. In what the court speaks of as matter of common knowledge, it confounds reputation with character. The whole edifice of constructive credibility and incredibility in courts of justice ought to be swept away. It is not long since every atheist or agnostic was constructively held to be a liar; though as John Stuart Mill said, the tribunals accepted the evidence of such atheists as were willing to lie, and rejected the testimony of those who preferred openly to avow a detested creed rather than tell a falsehood."

\section{Racial Degeneracy.}

To the Editor:-Apropos of your editorial in the JourNal, May 9, "Anthropology as a Branch of Medical Education," I have the honor to send you an extract from a letter of Dr. Jules Goldschmidt, Paris, France, late Medical Superintendent of the Funchal Leper Asylum, Madeira. I had sent Dr. Goldschmidt, my article "Racial Degeneracy in America; Goitre and Dwarfing," reprinted from the University Medical Magazine, January, 1896. My conclusions were:

"Racial degeneracy may be defined as non-resistance to influences inimical to the existence of the race. The individual who can not resist the disease-producing causes which are afloat, whether they be germs, climate, or whatever their nature, is physically degenerate. If the subject has lost all power of resisting the immoral tendencies which threaten the race, he is morally degenerate. A cretin is intellectually degenerate. A dwarf is a degenerate, because he has lost the faculty of growth. Goitre is a disease of racial degeneracy; it will only be found in those races in whom development has come to a stand-still, as the mixed races of South and Central America, the Cagots, some inferior layers of the Scotch, the mixed mulatto race, and the degenerate Indians of America, etc. Leprous races are degenerate, as the Eta race of Japan, some Central and South American races; the low caste Hin doos ; the poorer element of the Norwegian people. These diseases-. leprosy, goitre, dwarfing, cretinism-are evidences of the dying out of a race."

Dr. Goldschmidt writes: "What you say about pre-Columbian syphilis and leprosy, and that about racial degeneracy in America is of the highest interest and greatest importance for the history of diseases and for the theory of evolution.

"You remember what Darwin says in his 'Origin of Species' about the degeneration of the rabbit in the island of Porto Santo, some 60 miles to the north of Madeira and discovered a year before the latter island. Soon after the discovery, the ordinary rabbit was introduced into Porto Santo, and the still existing race is quite dwarfish compared to its ancestral continental prototype. . . . At last I must say a few words about tuberculosis and leprosy among the Indian tribes of North and South America. . . . Are not alcoholism, syphilis and tuberculosis the causes of the rapid disappearance of the aborigines in North America? Has leprosy any importance in this question of extinction? On the other hand are the cases of leprosy among the southern Indians not overwhelmingly more numerous than those among the northern? This question has a great importance to me especially as regards the natural disappearance of epidemics." Very truly yours,

Albert S. Ashmead, M.D.

\section{We All Talk Shop.}

To the Editor:-The thought expressed in the words which head this letter was suggested by reading in a secular newspaper an interview of which the following is an extract:

"Dr. George F. Shrady, the famous practitioner who was in attendance upon both President Garfield and President Grant, is an advisory physician to the Red Cross Hospital and a conservative man, who is widely quoted upon medical topics. He is editor of the Medical Record of this city, probably the most important medical journal published on the continent. At his home at 8 East Sixty-sixth Street Dr. Shrady thus expressed himself : * ****' 'It is like a knife-good in its place. There,' said the doctor, pointing to a knife in a glass case, 'is the knife that cut President Garfield, and the knife did him good; but I would not stick it into every sick man in my are."

The introduction to the interview is purely reportorial, and we have little to do with it. We like to know the man whose views upon matters we note, just the same as we like to know how much experience and authority there is back of an article in a medical journal. Hence, it comes about that when it is stated at the heading of a paper that the author is a member of three or four medical societies, an ex-member of one or two others, a lecturer or a professor in a medical college, and particularly if he is, etc., three or four times besides, we conclude at once that the article is worth the while. But what about "the knife in the glass case?" The reporter chanced to be seated so that he could see the knife in the "glass case." Exactly. He does not say whether the chair was fastened to the floor or not? Possibly the "glass case" was not fastened to the wall, but sitting on a table? A good artist always leaves out of the picture something for the imagination to supply.

One naturally asks, but why "glass"? That's it. "He pointed to the knife," hence, in this particular instance it is fair to presume that the case, that is to say, the "glass case," was transparent; a transparent "glass case" is aseptible, so we have it. Usually, the obsolete old Code is dragged into such discussions, but this interview was had in the Record office, and in that sanctum professional honor is free and untrammeled by codic restrictions.

$$
\text { J. L. Tracy, M.P }
$$

\section{PUBLIC HEALTH.}

What Is the Possible Minimum Death Rate?-The late Dr. Parkes fixed 17 per 1,000 as the "mortality incident to human nature," and in his time-the infancy of hygiene and sanitation---even that figure seemed Utopian. But what shall it be now fixed at in view of the reduced rate in Greater London. In 1894 the death rate had fallen from 20.5 for the decennium, 1881-90, to 17.7 per 1,000 ; and last year, 1895 , when the mean was 19.7 , there were sanitary areas in the great metropolis with the following figures: Wandsworth, 14.8; Lee, 14.5; Lewisham, 14.4; Stoke Newington, 13.4, and Hampstead, 12.

The Hygienic Importance of Amusements.-At the recent annual banquet of the French Société de Hygiène, one speaker dwelt upon the absolute necessity of providing amusements for the 